\title{
In Vitro Genotoxicity and Cytotoxicity in Murine Fibroblasts Exposed to EDTA, NaOCl, MTAD and Citric Acid
}

\author{
Juliana Soares Roter MARINS \\ Luciana Moura SASSONE ${ }^{1}$ \\ Sandra Rivera FIDEL ${ }^{1}$ \\ Daniel Araki RIBEIRO²
}

${ }^{1}$ Proclin Department, Dental School, UERJ - State University of Rio de Janeiro, Rio de Janeiro, RJ, Brazil

${ }^{2}$ Department of Bioscience, Dental School, UNIFESP - Federal University of São Paulo, Santos, SP, Brazil

\begin{abstract}
The aim of the present study was to evaluate the capacity of some root canal irrigants to induce genetic damage and/or cellular death in vitro. Murine fibroblast cells were exposed to ethylenediaminetetraacetic acid (EDTA), sodium hypochlorite (NaOCl), MTAD ${ }^{\text {TM }}$ and citric acid in increasing concentrations for $3 \mathrm{~h}$ at $37^{\circ} \mathrm{C}$. The negative control group was treated with vehicle control (phosphate buffer solution - PBS) for $3 \mathrm{~h}$ at $37^{\circ} \mathrm{C}$, and the positive control group was treated with methylmetanesulfonate, $1 \mu \mathrm{M}$. for $3 \mathrm{~h}$ at $37^{\circ} \mathrm{C}$. Cytotoxicity was assessed by the trypan blue test and genotoxicity was evaluated by the single cell gel (comet) assay. The results showed that exposure to $2.5 \%$ and $5 \% \mathrm{NaOCl}$ and $8.5 \%$ citric acid resulted in a significant cytotoxic effect. $\mathrm{NaOCl}$, EDTA and citric acid did not produce genotoxic effects with respect to the comet assay data for all evaluated concentrations. Although MTAD was not a cytotoxic agent, it showed significant genotoxic effects at all tested concentrations (ANOVA and Tukey's test; $\mathrm{p}<0.05$ ). NaOCl, EDTA and citric acid were found to be cytotoxic in a dose-dependent manner, but they were not genotoxic. MTAD did not cause cell death, but presented genotoxic effects.
\end{abstract}

Key Words: irrigants, single cell gel (comet) assay, DNA damage, cellular death.

\section{INTRODUCTION}

Successful endodontic therapy depends on a thorough chemomechanical preparation of the root canal system as well as a three-dimensional filling that provides complete seal of the spaces previously occupied by the canal contents. Mechanical instrumentation usually results in an amorphous irregular smear layer composed of inorganic and organic material covering canal surfaces (1) and plugging the dentinal tubules (1). Despite the controversy over maintaining or removing the smear layer, it has been shown that it may contain bacteria and protect them within the dentinal tubules (2). The smear layer has also been shown to hinder the penetration of intracanal disinfectants (3) into dentinal tubules and potentially compromise the seal of the root canal filling (4).

Several products and techniques capable of dissolving inorganic particles of the smear layer have been investigated and the ethylenediaminetetraacetic acid (EDTA) is widely used as the best option so far (5). Another efficient irrigant used for the same purpose is citric acid at different concentrations (6). Sodium hypochlorite $(\mathrm{NaOCl})$ at concentrations ranging from $0.5 \%$ to $5.25 \%$ is also used to dissolve organic tissue remnants (7). MTAD ${ }^{\mathrm{TM}}$ is a root canal irrigant that is a mixture of tetracycline isomer, citric acid and a detergent developed by Torabinejad et al (8). However, comparatively little literature is available on the genotoxicity and/or cytotoxicity of these compounds in mammalian cells. Genotoxicity tests can be defined as in vitro and in vivo assays designed to detect compounds that induce genetic damage including DNA damage, gene mutation, chromosomal breakage, altered DNA repair capacity and cellular transformation. It has been postulated that exposure of living tissues to cytotoxic

Correspondence: Profa. Dra. Luciana Moura Sassone, Boulevard vinte e oito de setembro, 157, Vila Isabel, 20550-030 Rio de Janeiro, RJ, Brasil. Tel: +55-21-2868-8355. e-mail: 1sassone@uerj.br 
agents can result in chronic cell injury, compensatory cell proliferation, hyperplasia, irritation, degeneration or tissue necrosis (9) and ultimately tumor development $(10,11)$. It is likely that proliferation may increase the risk of mutations within target cells and also be important in selective clonal expansion of exogenously or endogenously initiated cells from pre-neoplastic foci and eventually tumors (10). Thus, the DNA damage may diminish the self-repairing potential of tissue (12). In light of these considerations, genotoxicity and cytotoxicity assays gained widespread acceptance as an important and useful indicator of carcinogenicity.

Over the past decade, the single-cell gel (comet) assay in alkaline version was developed as a rapid, simple and reliable biochemical technique for evaluating deoxyribonucleic acid (DNA) damage in mammalian cells (13). The advantage of the alkaline version of the comet assay is the sensibility to detect low levels of DNA damage, low cost, requiring a small number of cells per sample and a short time to be completed (14). The basic principle of the single-cell gel (comet) assay is the migration of DNA fragments in an agarose matrix under electrophoresis. Under light microscopy, cells have the appearance of a comet, with a head (the nuclear region) and a tail containing DNA fragments or strands migrating toward the anode (13). Previous studies of our research group proved that the singlecell gel (comet) assay is a suitable experimental model to test the genotoxicity of compounds used in dental practice (15). Thus, this methodology was used in the present study to investigate the in vitro genotoxicity of EDTA, $\mathrm{NaOCl}, \mathrm{MTAD}$ and citric acid. The trypan blue test was used to monitor the cytotoxic effects. Certainly, such data will contribute for a better understanding of the behavior of these compounds on the cellular system.

\section{MATERIAL AND METHODS}

\section{Cell Culture}

Murine fibroblast cells (lineage 3T3-L1) were obtained from the American Type Culture Collection and cultured at $37^{\circ} \mathrm{C}$ in a humidified atmosphere of $5 \% \mathrm{CO}_{2} / 95 \%$ air. The cells were maintained in a growth medium containing the following constituents: Dulbecco's modified Eagle's medium (Invitrogen Corp., Grand Island, NY, USA) with $25 \mathrm{mmol} / \mathrm{L}$ glucose, 1 $\mathrm{mmol} / \mathrm{L}$ pyruvate, $4.02 \mathrm{mmol} / \mathrm{L}$ L-alanyl-glutamine and $10 \%$ fetal calf serum (Sigma Aldrich, St. Louis,
MO, USA).

Confluent cells were detached with $0.15 \%$ trypsin (Invitrogen Corp.) for $5 \mathrm{~min}$. After that, $2 \mathrm{~mL}$ of complete medium was added and the cells were centrifuged at 1000 $\operatorname{rpm}(180 \mathrm{~g})$ for $5 \mathrm{~min}$. Cell suspension was counted using a Neubauer chamber and seeded in 96-well microtitre plates (Corning Glass, Corning, NY, USA) at a density of $1 \times 10^{4}$ cells per well (at a concentration of $1 \times 10^{6} / \mathrm{mL}$ ).

\section{Cell Treatment}

The following materials were used: EDTA (4.25\%, 8.5\%, 17\%) (Merck \& Co., Inc., St. MO, Louis, USA), $\mathrm{NaOCl}(1.25 \%, 2.5 \%, 5.25 \%)$ (B'herzog, Rio de Janeiro, RJ, Brazil), MTAD $(0.1 \%, 1 \%, 10 \%)$ (Dentsply Tulsa Dental Specialties, Tulsa OK, USA) and citric acid $(5.25 \%, 10.5 \%, 21 \%)$ (Merck \& Co., Inc.). To determine the concentration-related effect significance, the tests were undertaken by increasing final concentrations taking into consideration the most commonly used concentrations in dental practice, during $3 \mathrm{~h}$ at $37^{\circ} \mathrm{C}$. The negative control group was treated with vehicle control (phosphate buffered saline - PBS), during $3 \mathrm{~h}$ at $37^{\circ} \mathrm{C}$ as well. For the positive control group, both cells were exposed to methyl methanesulfonate (MMS, Sigma Aldrich) at $1 \mu \mathrm{mol} / \mathrm{mL}$ during $3 \mathrm{~min}$ at $37^{\circ} \mathrm{C}$. Each treatment was performed consecutively three times to ensure reproducibility.

\section{Cytotoxicity Assay}

Cytotoxicity was assessed using trypan blue staining after the treatment (16). Briefly, a freshly prepared solution of $10 \mathrm{~mL}$ of $0.05 \%$ trypan blue in distilled water was mixed to $10 \mathrm{~mL}$ of each cell suspension for $5 \mathrm{~min}$, spread onto a microscope slide and covered with a coverslip. Nonviable cells appear blue stained. At least 200 cells were counted per treatment.

\section{Genotoxicity Assay}

The protocol used for single-cell gel (comet) assay followed the guidelines proposed by Tice et al. (13). Slides were prepared in duplicate per treatment. Thus, a volume of $10 \mu \mathrm{L}$ of treated or control cells $\left(\sim 1 \times 10^{4}\right.$ cells) was added to $120 \mu \mathrm{L}$ of $0.5 \%$ low-melting point agarose at $37^{\circ} \mathrm{C}$, layered onto a pre-coated slide with $1.5 \%$ regular agarose and covered with a coverslip. After brief agarose solidification in refrigerator, the 
coverslip was removed and the slides immersed into lysis solution (2.5 M NaCl, 100 mM EDTA; Merck \& Co., Inc.); $10 \mathrm{mM}$ Tris- $\mathrm{HCl}$ buffer $\mathrm{pH}=10$ (Sigma-Aldrich), $1 \%$ sodium sarcosinate (Sigma-Aldrich) with $1 \%$ Triton X-100 (Sigma-Aldrich) and 10\% DMSO (Merck \& Co., Inc.) for about $1 \mathrm{~h}$. Prior to electrophoresis, the slides were left in alkaline buffer $(0.3 \mathrm{mM} \mathrm{NaOH}$, Merck \& Co., Inc.) and 1 mM EDTA (Merck \& Co., Inc., $\mathrm{pH}>13$ ) for $20 \mathrm{~min}$ and electrophoresed for additional $20 \mathrm{~min}$ at $25 \mathrm{~V}(0.86 \mathrm{~V} / \mathrm{cm})$ and $300 \mathrm{~mA}$. During electrophoresis under alkaline conditions, cells with damaged DNA displayed increased rates of DNA migration to the anode. The increase in DNA migration rate results from the formation of smaller fragments of DNA caused by double-strand breaks, single-strand breaks and alkali labile sites. Smaller fragments of DNA migrate further in the electric field compared with intact DNA and the cellular lysates thus resemble a "comet" with a bright fluorescent head and a tail region (11). After electrophoresis, the slides were neutralized in $0.4 \mathrm{M}$ Tris$\mathrm{HCl}(\mathrm{pH}=7.5)$ for $15 \mathrm{~min}$, fixed in absolute ethanol and stored at room temperature until the moment of analysis. All of the steps described above were conducted in the dark to prevent additional DNA damage.

Fifty randomly captured comets per treatment ( 25 cells from each slide) (17) were examined blindly by one expert observer at $\times 400$ magnification using an image analysis system (Comet Assay II; Perceptive Instruments, Haverhill, UK). Two parameters were estimated to determine the level of DNA damage: tail moment (product of tail DNA/total DNA by the center

\section{n cell viability (\%) Sodium Hypochlorite}

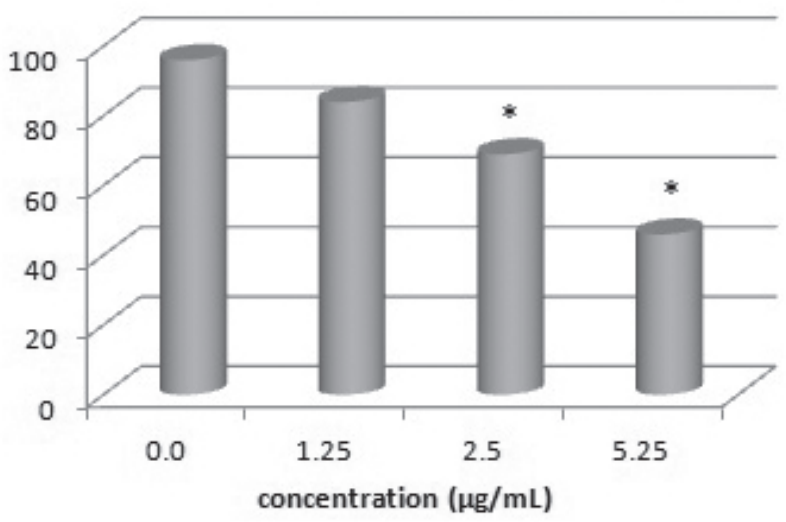

Figure 1. Effects of serial concentrations of $\mathrm{NaOCl}$ on trypan blue test. Results are expressed as the mean percentage of control (mean $\pm \mathrm{SD}$ ). ${ }^{*} \mathrm{p}<0.05$ when compared with negative control. of gravity) and tail intensity (percentage of DNA in the tail). In none of the experiments there was a significant difference between these parameters. Therefore, the tail moment was chosen for the presentation of results.

\section{Statistical Analysis}

Data from the cytotoxicity assay and singlecell gel (comet) assay (tail moment) were assessed by one-way ANOVA followed by Tukey's post-hoc test, using SigmaStat software, version 1.0 (Jandel Scientific, Rafael, CA, USA). A p value less than 0.05 was considered statistically significant.

\section{RESULTS}

Exposure of murine fibroblast cells to $\mathrm{NaOCl}$ resulted in a significant cytotoxic effect for all concentrations, except for the lowest one $(1.25 \%)$ used in this study, when compared with the negative control. Such findings are summarized in Figure 1. Citric acid also induced cytotoxic effects as depicted by the percentage of viable cells remaining when higher concentrations (10.5\% and 21\%) were used (Fig. 2). EDTA produced some evidence of cytotoxicity only at the highest tested concentration (Fig. 3) and MTAD did not affect the murine cells in any of the tested concentration (Fig. 4).

Regarding the genotoxic parameters, $\mathrm{NaOCl}$ did not induce DNA damage in murine fibroblast cells. The same occurred to EDTA and citric acid, which did not

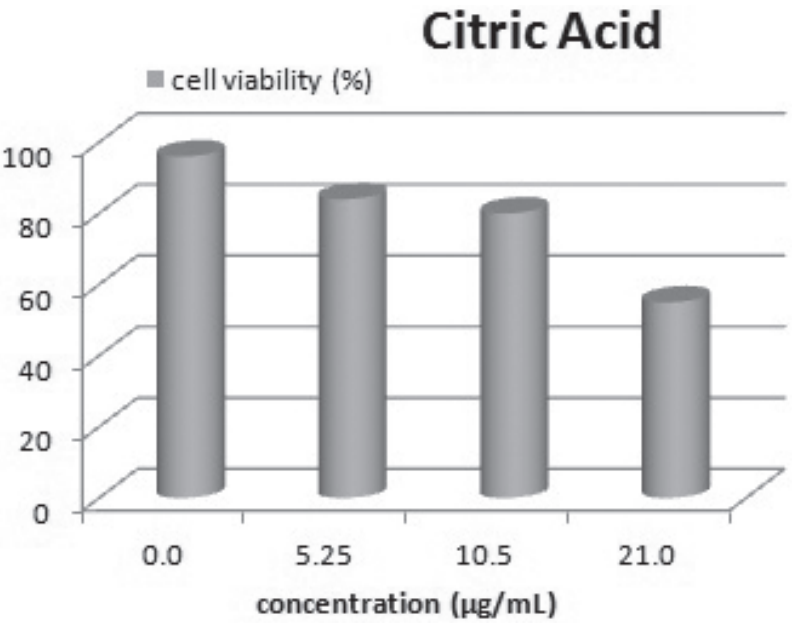

Figure 2. Effects of serial concentrations of citric acid on trypan blue test. Results are expressed as the mean percentage of control (mean $\pm \mathrm{SD}$ ). ${ }^{*} \mathrm{p}<0.05$ when compared with negative control. 
differ significantly $(p>0.05)$ from the negative control group. However, MTAD showed genotoxic potential at all tested concentrations when compared with the negative control group $(\mathrm{p}<0.05)$. These data are shown in Table 1. For comparative purposes, the single-cell gel (comet) assay was able to detect a significant increase in the tail moment of the positive control (MMS) when compared with negative control.

\section{DISCUSSION}

This study evaluated in vitro the genotoxic and cytotoxic damages induced by four endodontic irrigants (EDTA, NaOCl, MTAD and citric acid). The investigation was conducted using the trypan blue and single-cell gel (comet) assays. To the best of our

\section{EDTA}

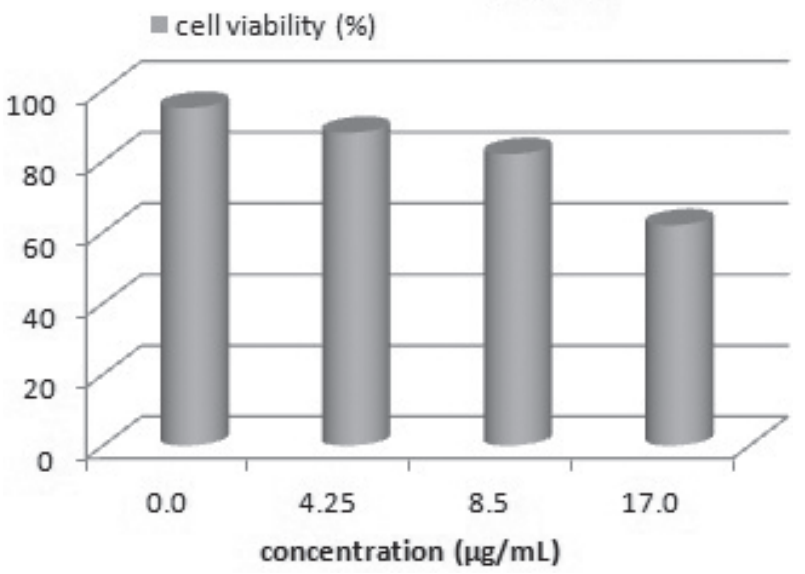

Figure 3. Effects of serial concentrations of EDTA on trypan blue test. Results are expressed as the mean percentage of control (mean $\pm \mathrm{SD}$ ). ${ }^{*} \mathrm{p}<0.05$ when compared with negative control. knowledge, this approach had not yet been addressed.

In vitro studies are simple, inexpensive to perform, provide a significant amount of information can be conducted under controlled conditions and may elucidate the mechanisms of cellular toxicity (18). Cell culture studies are commonly used in the evaluation of genotoxicity and cytotoxicity. The results obtained from these in vitro assays might be indicative of the effects observed in vivo (18). The choice of this cell line, i.e. murine fibroblast cells, permits an accurate evaluation of the changes, excluding factors such as age, metabolic and hormonal states of the donor, which might influence the cell in a primary culture.

The trypan blue exclusion test can be used to indicate cytotoxicity, where dead cells take up the blue stain of trypan blue, whereas the live cell have yellow

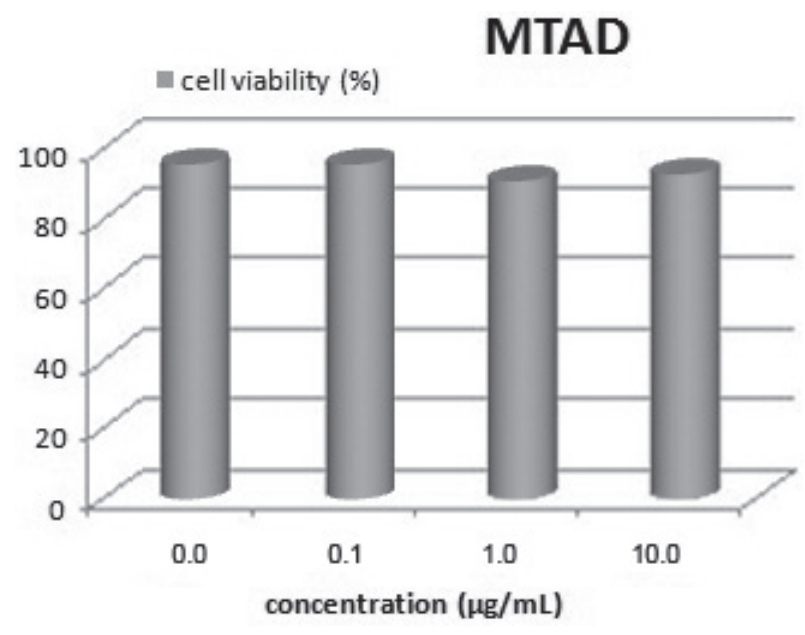

Figure 4. Effects of serial concentrations of MTAD on trypan blue test. Results are expressed as the mean percentage of control (mean $\pm \mathrm{SD}$ ). ${ }^{*} \mathrm{p}<0.05$ when compared with negative control.
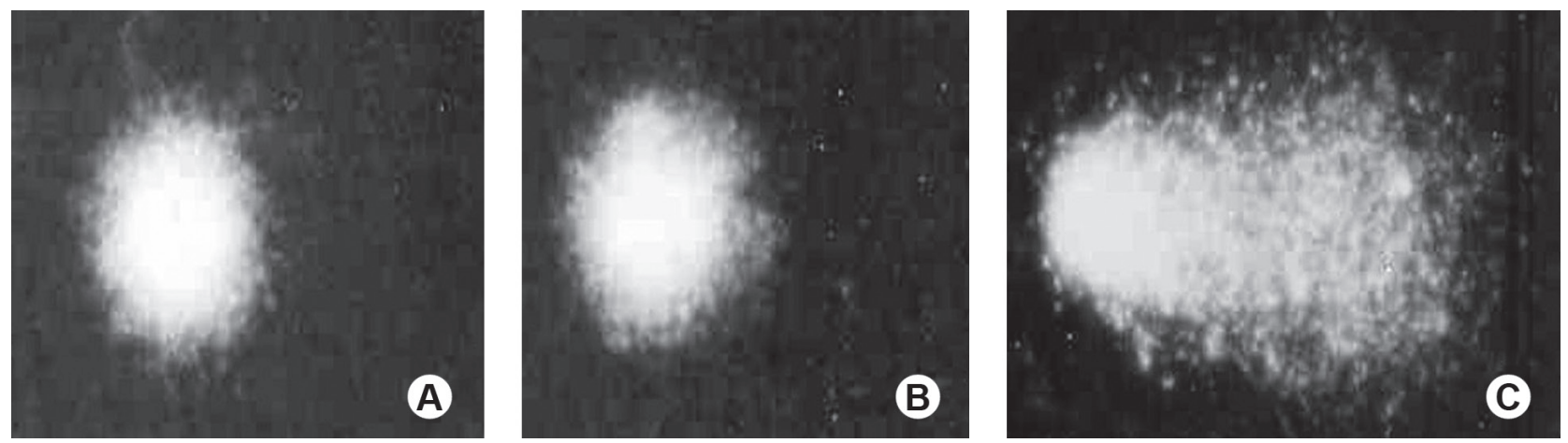

Figure 5. Tail moment. (A) cell with intact DNA, (B) cell with some DNA fragmentation and (C) cell with high level of DNA fragmentation. 
nuclei. In a study, EDTA reduced macrophage viability significantly more than citric acid (17). In this study, the trypan blue assay revealed that citric acid was cytotoxic in the highest tested concentrations, and others as slightly non-cytotoxic. On the other hand, Navarro-Escobar et al. (19) observed that citric acid solution was cytotoxic in a $15 \%$ concentration. In the present study, EDTA produced some evidence of cytotoxicity only at the highest tested concentrations and the same was observed by others (20). Furthermore, MTAD showed no cytotoxic potential in any tested concentration (12). In contrast, $\mathrm{NaOCl}$ was severely cytotoxic at practically all tested concentrations in this study, confirming a recent report conducted by Missotten et al. (21), in which no surviving ocular cells were observed after treatment of $3 \mathrm{~min}$ with $0.5 \% \mathrm{NaOCl}$ in vitro. As a whole, these findings confirm the idea that the cell membrane was the main target for the toxic agent and that the damage occurred quickly.

The alkaline version of the single-cell gel (comet) assay is sensitive for a wide variety of DNA lesions. Among them are single- and double strand breaks, oxidative DNA base damage, alkali-labile sites including abasic and incomplete repair sites and DNA-DNA/DNAprotein/DNA-drug cross-linking in any eukaryotic cell (11). Tail moment is a virtual measure calculated by the computerized image analysis system considering both the length of DNA migration in the comet tail and the tail intensity. This parameter is one of the best indices of induced DNA damage among the various parameters calculated by this method (13).

Cytotoxicity assessment is an integral part of the single-cell gel (comet) assay. As cytotoxicity produces strand breaks that show up as increased DNA migration, it is recommended that single-cell gel (comet) assay should not be performed on samples showing more than $30 \%$ cytotoxicity (22). In the present study, as well as in previous investigations of our research group (15, 23 ) using the single-cell gel (comet) assay, the comets without clearly identifiable heads (i.e. comets with most of their DNA in the tails after the electrophoresis) were have always excluded during the image analysis. Although it should be emphasized that it is still not completely understood what these 'clouds' actually represent, this type of comet was excluded on the basis of the assumption that these cells represent dead cells, resulting from putative cytotoxic effects rather than primary DNA-damage following a direct interaction between DNA and a genotoxic agent (23). The approach of excluding comets with practically all DNA in the tail after the electrophoresis when evaluating potential genotoxicity in the single-cell gel (comet) assay has been used elsewhere (23).

On the basis of tail moment data, the results of this study pointed out that the alkaline single-cell gel (comet) assay in the used experimental conditions did not detect the presence of DNA damage after a treatment by $\mathrm{NaOCl}$, EDTA or citric acid. By comparison, some authors have identified chromosome aberrations in SHE cells after treatment with EDTA, whereas $\mathrm{NaOCl}$ exhibited a negative response (24). It is important to stress that the single-cell gel (comet) assay does not necessarily predict the mutagenic potential of chemical compounds. Moreover, the genotoxicity of agents can be modulated in combination with other DNA-damaging agents that are

Table 1. Genotoxic effects (in arbitrary units) of serial concentrations (\%) of EDTA, NaOCl, MTAD and citric acid using the singlecell gel (comet) assay.

\begin{tabular}{|c|c|c|c|c|c|c|c|}
\hline \multicolumn{2}{|c|}{ EDTA } & \multicolumn{2}{|c|}{$\mathrm{NaOCl}$} & \multicolumn{2}{|c|}{ MTAD } & \multicolumn{2}{|c|}{ Citric acid } \\
\hline $\begin{array}{c}\text { Concentration } \\
(\%)\end{array}$ & $\begin{array}{c}\text { Tail } \\
\text { moment }\end{array}$ & $\begin{array}{c}\text { Concentration } \\
(\%)\end{array}$ & $\begin{array}{c}\text { Tail } \\
\text { moment }\end{array}$ & $\begin{array}{c}\text { Concentration } \\
(\%)\end{array}$ & $\begin{array}{c}\text { Tail } \\
\text { moment }\end{array}$ & $\begin{array}{c}\text { Concentration } \\
(\%)\end{array}$ & $\begin{array}{c}\text { Tail } \\
\text { moment }\end{array}$ \\
\hline $0.0^{\dagger}$ & $0.7 \pm 0.3$ & $0.0^{\dagger}$ & $0.7 \pm 0.3$ & $0.0^{\dagger}$ & $0.7 \pm 0.3$ & $0.0^{\dagger}$ & $0.7 \pm 0.3$ \\
\hline 4.25 & $0.5 \pm 0.2$ & 1.25 & $0.7 \pm 0.1$ & 0.1 & $1.2 \pm 1.0$ & 5.25 & $0.5 \pm 0.4$ \\
\hline 8.5 & $0.8 \pm 0.2$ & 2.5 & $*$ & 1.0 & $1.8 \pm 1.6$ & 10.5 & $0.9 \pm 0.5$ \\
\hline 17 & $0.6 \pm 0.4$ & 5.25 & $*$ & 10 & $2.9 \pm 2.7$ & 21 & $*$ \\
\hline
\end{tabular}

$(*)$ Not tested due to more than $30 \%$ cytotoxicity. $(\dagger)$ Negative control. 
present in the environment following chronic genotoxic injury at low levels. This could partially explain these results. Therefore, the discrepancy may result from cells of different species, different culture conditions and different evaluated experimental conditions (25). Taken all together, there seems to be evidence that $\mathrm{NaOCl}$, EDTA and citric acid cannot induce genetic damage in murine fibroblast cells. MTAD was the only tested solution showing genotoxicity at all concentrations; however, for a more detailed evaluation of the genotoxic potential of this chemical, a set of tests is recommended.

In conclusion, the present study indicates that $\mathrm{NaOCl}$, EDTA and citric acid are cytotoxic agents, being the effect stronger for $\mathrm{NaOCl}$. All these chemicals did not induce genetic damage in vitro. Despite the absence of cytotoxicity, MTAD showed significant genotoxic effects at all tested concentrations. Since DNA damage is an important step in events ranging from carcinogen exposure to cancer, these results represent a potential alert for a correct evaluation of the potential health risks associated with exposure to these compounds that are present in some materials used in clinical practice.

\section{RESUMO}

O objetivo do presente estudo foi avaliar a capacidade de alguns irrigantes endodônticos em induzir danos genéticos e/ou morte celular in vitro. Células de fibroblastos murinos foram expostas ao ácido etilenodiaminotetracético (EDTA), hipoclorito de sódio $(\mathrm{NaOCl}), \mathrm{MTAD}^{\mathrm{TM}}$ e ácido cítrico em concentrações crescentes durante $3 \mathrm{~h}$ a $37^{\circ} \mathrm{C}$. O grupo controle negativo foi tratado com solução tampão fosfato - PBS por $3 \mathrm{~h}$ a $37^{\circ} \mathrm{C}$ e o grupo controle positivo foi tratado com metilmetanesulfonato a $1 \mu \mathrm{M}$ por 3 $\mathrm{h}$ a $37^{\circ} \mathrm{C}$. A citotoxicidade foi testada pelo azul de tripan e a genotoxicidade foi avaliada pelo teste do cometa. Os resultados apontaram que a exposição ao $\mathrm{NaOCl}$ a $2,5 \%$ e $5 \%$, e ácido cítrico a $21 \%$ resultou em efeitos citotóxicos significativos. $\mathrm{O} \mathrm{NaOCl}$, EDTA e o ácido cítrico não produziram efeitos genotóxicos no que diz respeito aos dados obtidos pelo ensaio do Cometa em todas as concentrações testadas. Embora o MTAD não tenha sido um agente citotóxico, mostrou efeitos genotóxicos significativos em todas as concentrações testadas (ANOVA e teste de Tuckey; $\mathrm{p}<0,05)$. O NaOCl, o EDTA e o ácido cítrico mostraram-se citotóxicos de maneira dose-dependente, mas não genotóxicos. Por outro lado, apesar do MTAD não ter causado a morte celular, foi genotóxico em todas as concentrações testadas.

\section{ACKNOWLEDGEMENTS}

The authors are thankful to Maria Cristina Severino for her technical assistance. This work was supported by grants from FAPESP (Fundação de Amparo à Pesquisa do Estado de São Paulo, Grant number: 07/01228-4). DAR is a recipient of the CNPq fellowship.

\section{REFERENCES}

1. McComb D, Smith DC. A preliminary scanning electron microscopic study of root canals after endodontic procedures. J Endod 1975;1:238-242.

2. Torabinejad M, Handysides R, Khademi AA, Bakland LK. Clinical implications of the smear layer in endodontics: a review. Oral Surg Oral Med Oral Pathol Oral Radiol Endod 2002;94:658-666.

3. Orstavik D, Haapasalo M. Disinfection by endodontic irrigants and dressings of experimentally infected dentinal tubules. Endod Dent Traumatol 1990;6:142-149.

4. Shahravan A, Haghdoost AA, Adl A, Rahimi H, Shadifar F. Effect of smear layer on sealing ability of canal obturation: a systematic review and meta-analysis. J Endod 2007;33:96-105.

5. Aktner BO, Bilkay U. Smear layer removal with different concentrations of EDTA-ethylenediamine mixtures. J Endod 1993:19;228-231.

6. Eldeniz AU, Erdemir A, Belli S. Effect of EDTA and citric acid solutions on the microhardness and the roughness of human root canal dentin. J Endod 2005;31:107-110.

7. Grandini S, Balleri P, Ferrari M. Evaluation of Glyde File Prep in combination with sodium hypochlorite as a root canal irrigant. $\mathrm{J}$ Endod 2002;28:300-303.

8. Mally A, Jagetia JK. Non-genotoxic carcinogens: early effects on gap junctions, cell proliferation and apoptosis in the rat. Toxicology 2002;180:233-248.

9. Cunha SA, Rached FJ Jr, Alfredo E, León JE, Perez DE. Biocompatibility of sealers used in apical surgery: a histological study in rat subcutaneous tissue. Braz Dent J 2011;22:299-305.

10. Zhang W, Torabinejad M, Li Y. Evaluation of cytotoxicity of MTAD using the MTT-Tetrazolium method. J Endod 2003;10:654657.

11. Visalli G, Baluce B, Maestra SL, Micale RT, Cigano L, Di Flora $\mathrm{S}$, et al.. Genotoxicity damage in the oral mucosa cells of subjects carrying restoratives dental fillings. Arch Toxicol 2012 [Epub ahead of print. DOI 10.1007/s00204-012-0915-2].

12. Kaya A, Undeger U, Aydin S, Omurlu H, Başaran, N. Genotoxicity evaluation of dentine bonding agents by comet assay. Int Endod J 2011;44:807-816.

13. Tice RR, Agurell E, Anderson D, Burlinson B, Hartmann A, Kobayashi H, et al.. Single cell gel/comet assay: guidelines for in vitro and in vivo genetic toxicology testing. Environ Mol Mutagen 2000;35:206-221.

14. Baraba A, Zelježić D, Kopjar N, Miadinić M, Anić I, Miletić I. Evaluation of cytotoxicity and genotoxic effects of two resin based root canal sealers and their components on human leucocytes in vitro. Int Endod J 2011,44:652-661.

15. Braz MG, Camargo EA, Salvadori DM, Marques ME, Ribeiro DA. Evaluation of genetic damage in human peripheral lymphocytes exposed to mineral trioxide aggregate and Portland cements. J Oral Rehabil 2006;33:234-239.

16. Mckelvey-Martin VJ, Green MHL, Schmezer P, Pool-Zobel BL, De Méo MP, Collins A. The single cell gel electrophoresis assay (comet assay): a European review. Mutat Res 1993;288:47-63.

17. Hartmann A, Agurell E, Beevers C, Brendler-Schwaab S, Burlinson B, Clay P, et al.. Recommendations for conducting the in vivo alkaline comet assay. Mutagenesis 2000;18;45-51.

18. Geurtsen W. Substances released from dental resin composites and glass ionomer cements. Eur J Oral Sci 1998;106:687-695.

19. Navarro-Escobar E, Gonzalez-Rodriguez M, Ferrer-Luque P. Cytotoxic effects of two acid solutions and $2.5 \%$ sodium hypochlorite used in endodontic therapy. Med Oral Pathol Cir Bucal 2010;15:e90-e94. 
20. Serper A, Calt S, Dogan AL, Guc D, Ozçelik B, Kuraner T. Comparison of the cytotoxic effects and smear layer removing capacity of oxidative potential water, $\mathrm{NaOCl}$ and EDTA. J Oral Sci 2001;43:233-238.

21. Missotten GS, Keijser S, de Keizer RJ. Cytotoxic effect of sodium hypochlorite $0.5 \%(\mathrm{NaOCl})$ on ocular melanoma cells in vitro. Orbit 2008;27:31-35

22. Eisenbrand G, Pool-Zobel BL, Baker M, Balls M, Blaauboer BJ, Boobis A, et al.. Methods in vitro toxicology. Food Chem Toxicol 2002:40:193-236.

23. Ribeiro DA, Pereira PC, Machado JM, Silva SB, Pessoa AW, Salvadori DM. Does toxoplasmosis cause DNA damage?
An evaluation in isogenic mice under normal diet or dietary restriction. Mutat Res 2004;559:169-176.

24. Hagiwara M, Watanabe E, Barrett JC, Tsutsui T. Assessment of genotoxicity of 14 chemical agents used in dental practice: ability to induce chromosome aberrations in Syrian hamster embryo cells. Mutat Res 2006;603:111-120.

25. Li Y, Kuan Y, Lee S, Huang F, Chang Y. Cytotoxicity and genotoxicity of chlorhexidine on macrophages in vitro. Environ Toxicol 2012 [Epub ahead of print. DOI 10,1002/tox. 21771].

Received March 3, 2012 Accepted October 31,2012 